\title{
Characterizations of Drinking Water Quality for Populations of Hann Bel-Air (Dakar, Senegal)
}

\author{
Alassane Thiam ${ }^{*}$, Amadou Babacar Sarr ${ }^{2}$, Serigne Modou Sarr ${ }^{3}$ \\ ${ }^{1}$ UFR Sciences de l'Ingénieur, Université de Thiès, Thiès, Sénégal \\ ${ }^{2}$ Institut de Formation et de Recherches Médicales, Dakar, Sénégal \\ ${ }^{3}$ Institut Supérieur de Formation Agricole et Rurale, Université Alioune Diop, Bambey, Sénégal \\ Email: *alassane.thiam@univ-thies.sn
}

How to cite this paper: Thiam, A., Sarr, A.B. and Sarr, S.M. (2020) Characterizations of Drinking Water Quality for Populations of Hann Bel-Air (Dakar, Senegal). Journal of Water Resource and Protection, 12, 898-909.

https://doi.org/10.4236/jwarp.2020.1210052

Received: November 22, 2019

Accepted: October 27, 2020

Published: October 30, 2020

Copyright $\odot 2020$ by author(s) and Scientific Research Publishing Inc. This work is licensed under the Creative Commons Attribution International License (CC BY 4.0).

http://creativecommons.org/licenses/by/4.0/

\begin{abstract}
Populations of Hann Bel-Air municipality are supplied with drinking water from taps water of "Sénégalaise Des Eaux" (SDE) and Jambar pumps which capturie directly the groundwater. This municipality is characterized by a strong environmental pollution which can affect the quality of drinking water. To determine actual quality of that water, 10 samples were taken and analyzed. Physico-chemical results have shown that tap water is more suitable for domestic consumption than Jambar pump water. The results show that physical parameters such as electrical conductivity (maximum value of 2671 $\mu \mathrm{S} / \mathrm{cm}$ ) exceed World Health Organization standard. The $\mathrm{pH}$ of the water from Jambar pumps is between 6.04 and 6.09, which demonstrates the aggressive character of that water. For tap water, $\mathrm{pH}$ values of 7.03 to 7.09 demonstrate their alkalinity. For chemical analyses, bicarbonates and sulphates concentrations respectively meet World Health Organization standards. Tap water meets World Health Organization standard for nitrates. With respect to chloride, the threshold of $250 \mathrm{mg} / \mathrm{L}$ is exceeded at all levels, but we note that high chloride concentrations are part of the exemptions granted to SDE. Tap water and water from water table have concentrations of calcium, potassium, iron and magnesium irreproachable. For sodium, EP3, EP4 and P5 samples from the web exceed World Health Organization standard with a peak of $310.27 \mathrm{mg} / \mathrm{L}$. Tap water is more drinkable than groundwater but its quality needs to be improved and especially controlled for the well-being and sustainable health of consumers.
\end{abstract}

\section{Keywords}

Hann Bel-Air, Water Resources, Physico-Chemical Analyses, Quality 


\section{Introduction}

In Senegal, water remains an essential resource for the sustainable well-being of the population and the country generally has sufficient water resources to supply populations through surface and groundwater [1]. Until the mid-twentieth century, water was considered an inexhaustible wealth that each user could appropriate, possess and exploit according to their needs [2], as well as manage through all human civilizations. Up to the mid twentieth century, water was considered as inexhaustible resource that people could have and exploit according to their needs [2]. This resource was then willingly managed throughout all societies. In many parts of the Dakar region groundwater is polluted by discharges linked to the lack of sanitation (bacteria, chemicals, heavy metals, nitrates) [3]. Today, more than one billion people in the world do not have access to basic water supplies and half of the population in the developing countries suffers from diseases caused by water contamination [1] [4]. The risks to human health are undoubtedly the most serious and widespread problem with water. Every year, about 3.5 million people die from problems related to access to water, sanitation and hygiene, especially in developing countries [1] [5]. Diarrhea, often caused by the consumption of contaminated water, is estimated to kill more than 1.5 million children under 5 every year [6].

Populations of the municipality of Hann Bel Air (Dakar, Senegal) are using water from Guiers Lake and groundwater. Threats also weigh on the future of urban agriculture in Dakar. Disturbing soil depletion and difficult access to water have been highlighted in various studies [7] [8]. The heavy pollution and salinization of the aquifer of the Niayes area of Dakar, caused by over-exploitation, the use of chemical inputs and the lack of sanitation network, have greatly destabilized the functioning of agricultural activities by disrupting access to water. Water from Guiers Lake is transported by pipelines and distributed by a tap system. Groundwater of the area is captured by drilling and distributed by Jambar pumps. Given the lack of sanitation and urbanization, the problem of water quality can arise. Water quality assessment depends on several parameters: organoleptic (color, smell, and flavor), physical-chemical (electrical conductivity, turbidity, mineral and organic contents) and bacteriological (presence or absence of pathogens). Organoleptic parameters are qualitative very valuable indicators. Instead, physico-chemical and bacteriological parameters are quantitative and appreciated by established norms [9].

Gradual degradation of groundwater quality in some aquifers is due to salinization, inadequate sanitation systems and iron presence [10]. This creates the nagging issue of water quality distributed by the SDE in some neighborhoods of Dakar city, including Hann Bel-Air [10]. This non-quality of water is mainly due to chloride, iron and sometimes nitrate ions, which are often at concentrations above the thresholds established by World Health Organization instructions (2017), to which refer the Senegalese regulation on the quality of the water. In this situation, monitoring water quality is entrusted to both SDE operating com- 
pany and SONES Heritage Company. This work is part of the overall improvement of drinking water quality consumed in Hann Bel-Air municipality.

\section{Description of Study Site}

The District of Hann Bel-Air created in 1996 which sets its limits (Figure 1), is subdivided into three natural areas separated by the road from North Front and Hann Bel Air Ring in the center with an area of about $12 \mathrm{~km}^{2}$. Hann Bay is located on the eastern side of the Cape Verde peninsula. It extends from Bel-Air point to the village of Mbao. Its urbanization, correlated with spatial constraints, puts pressure on the environment and has resulted in a noticeable deterioration of natural resources. These situations pose a crucial problem of monitoring the management and planning of the borough council, which is evolving at a worrying speed. As a result, land use has stimulated the interest of multiplying studies to provide an adequate response to the problems experienced in these urban areas [11] Coastal erosion is weak along the bay and current traffic is not conducive to dispersal of pollutants: shelter effect. The phenomenon of upwelling brings some of the contaminated water back to the coast. The municipality of Hann Bel-Air is one of the most polluted areas of Dakar city [10] (Figure 1). This town shelters the bay of Hann which is both a naturally beautiful site, which certainly rivals the most beautiful bays in the world and an equally rare example of degradation by severe pollution and nuisance. We know the causes of this critical ecological situation, related to the proximity of the industrial zone and its discharges of non-remediated and uncontrolled effluents, and the massive eutrophication caused by urban effluents [10]. For the water consumption, the population of Hann Bel-Air has two sources that are: The water from taps distributed by the SDE and the water of Jambar pumps coming directly from the groundwater. Although tap water is under surveillance, it is contentious in Hann Bel-Air where the majority of the population doubts its potability. According to some research, the water distributed in Dakar more precisely in the zone of Yarakh does not respect the standards according to Baldé, 2006 [8]. The choice of our subject is justified by the need to know if the water consumed in the commune of Hann Bel-Air is of quality.

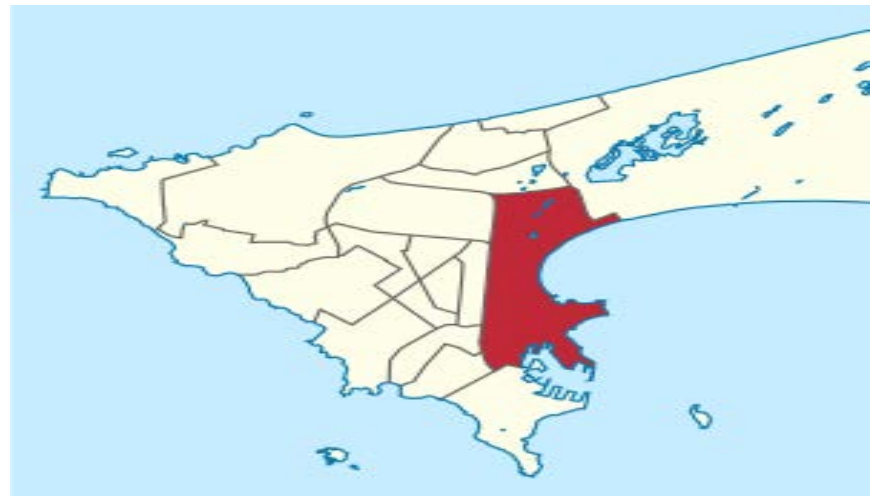

Figure 1. Situation of Hann Bel-Air Municipality in Dakar. 


\section{Sampling Waters}

10 water samples were taken on February 14, 2018, including five (05) at the Jiambar pumps and 05 at the taps for physico-chemical analyzes. For Jambar pumps, we first pumped three (03) shots before taking the samples. For tap water sampling, stagnant water in the pipes was removed by opening the valve at maximum flow for 5 seconds, then returning to medium flow by presenting the clean bottle under the tap and closing tightly. Samples names are for tap water ER1, ER2, ER3, ER4, ER5 and EP1, EP2, EP3, EP4, EP5 for Jambar pumps. All physico-chemical analyzes were done at the Laboratory of Hydrochemistry of the Department of Geology-Faculty of Science and Technology-University Cheikh Anta DIOP-DAKAR (Senegal).

\section{Results and Discussions}

The physical parameters discussed in this study are the temperature, $\mathrm{pH}$ and electrical conductivity of faucet water and Jambar pumps WORLD HEALTH ORGANIZATION quality reference values are shown in Table 1.

\subsection{Temperature}

The temperature values obtained in the tap water ER1, ER2, ER3, ER4, ER5 vary from $18.2^{\circ} \mathrm{C}$ to $20.9^{\circ} \mathrm{C}$ whereas in the water of Jambar pumps EP1, EP2, EP3, EP4, EP5 they vary from $18.6^{\circ} \mathrm{C}$ to $21.1^{\circ} \mathrm{C}$ (Figure 2). In comparison, the water temperatures of Jambar pumps are much higher than those of tap water (Figure 1).

These temperatures are proportional to the temperature of the sampling day of February $15-2018$ at $22^{\circ} \mathrm{C}$ and meet the standard of $25^{\circ} \mathrm{C}$ established by

Table 1. World Health Organization quality reference values.

\begin{tabular}{cc}
\hline Parameters & References of quality \\
\hline Temperature $\left({ }^{\circ} \mathrm{C}\right)$ & $25^{\circ} \mathrm{C}$ \\
$\mathrm{pH}$ & $6,5<\mathrm{pH}<9$ \\
Electrical Conductivity $(\mu \mathrm{S} / \mathrm{cm})$ & $180<\mathrm{EC}<1000$ at $20^{\circ} \mathrm{C}$ \\
\hline
\end{tabular}

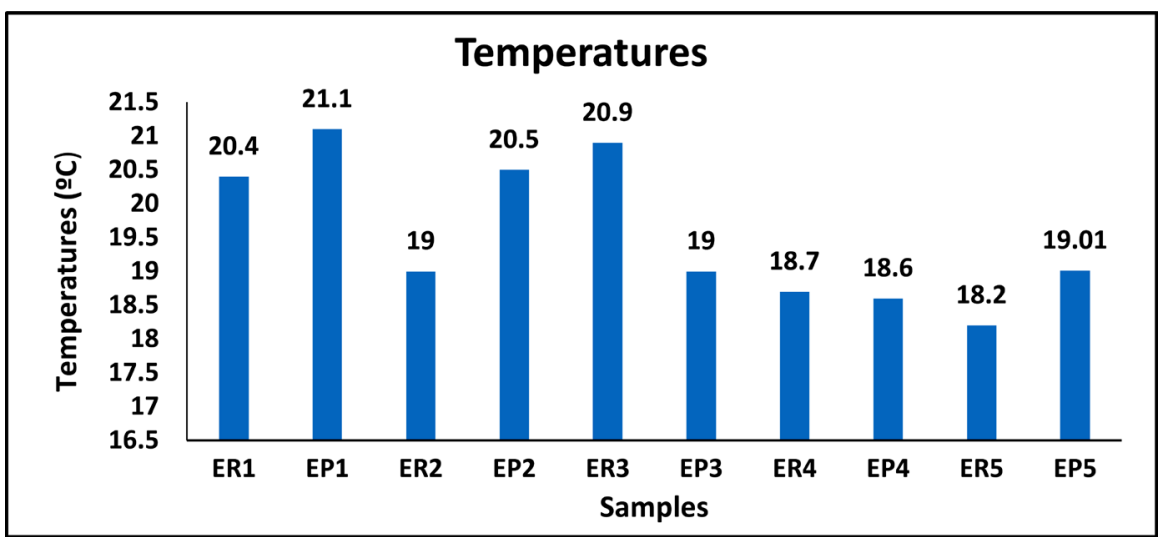

Figure 2. Temperatures of water samples. 
World Health Organization. The temperature of the water is strongly influenced by the environmental conditions related to the geographical position and the climate. High water temperatures stimulate the growth of microorganisms and can aggravate problems with taste, odors, stains and corrosion [12].

In drinking water supply networks, the temperature of the environment has a very strong influence on the temperature of the water because the pipes are often exposed to solar and nocturnal radiation. Therefore, it is important to determine the ambient air temperature when taking the temperature of the water to be studied.

\subsection{Electrical Conductivity}

The values of the electrical conductivity of all 10 samples vary from 1176 to 2671 $\mu \mathrm{S} / \mathrm{cm}$ far exceeding the World Health Organization threshold of $1000 \mu \mathrm{S} / \mathrm{cm}$ (Figure 3).

This shows that tap water and Jambar pumps water used at Hann Bel-Air are very rich in mineral elements. This high mineralization can lead to scaling when the calcium salts are excessive. However, excessive values of electrical conductivity may have laxative effects in humans.

\section{3. $\mathrm{pH}$}

The $\mathrm{pH}$ values of the tap water vary from 7.01 to 7.09 , whereas they are lower for Jambar pump water (6.04 to 6.9) (Figure 4). This slightly basic water is exposed to the risk of spreading of pathogens and bacteria harmful to the health of consumers within the municipality because $\mathrm{pH}$ above 7 make water more or less alkaline and decreases the effectiveness of disinfection at chlorine.

The water from the ground $\mathrm{pH}$ values between 6.04 and 6.9 with a slight acidity shows an high risk of corrosion of the pumps, contrariwise this risk is mitigated by the fact that the water is never stored in the pumps but in the ground water.

\subsection{Bicarbonates $\left(\mathrm{HCO}_{3}^{-}\right)$}

$\mathrm{HCO}_{3}^{-}$concentrations vary from $25.26 \mathrm{mg} / \mathrm{L}$ to $136.35 \mathrm{mg} / \mathrm{L}$ (Figure 5). $\mathrm{HCO}_{3}^{-}$

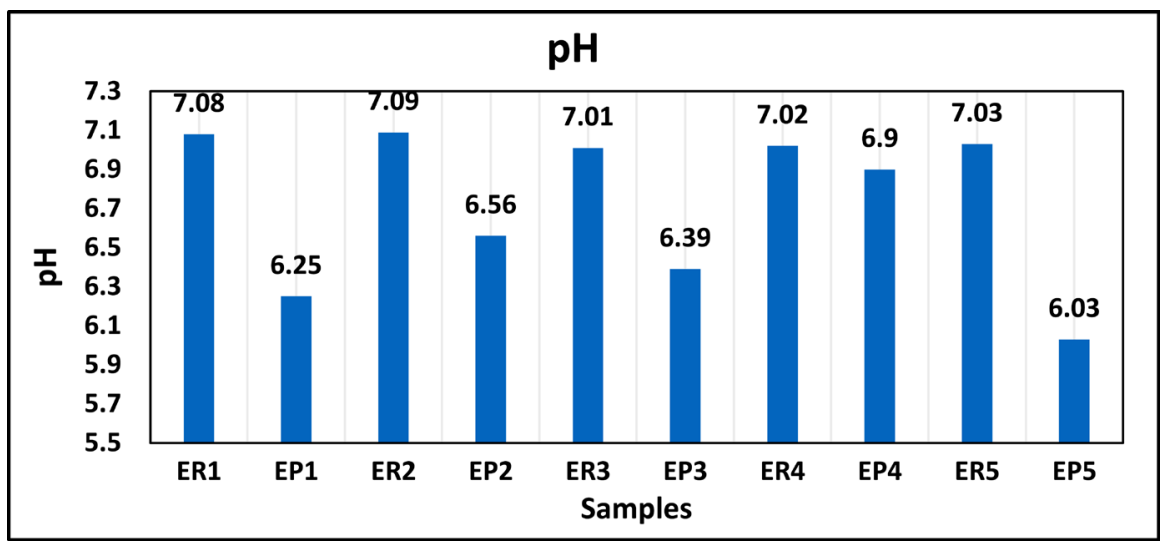

Figure 3. Variations of electrical conductivity of water samples. 


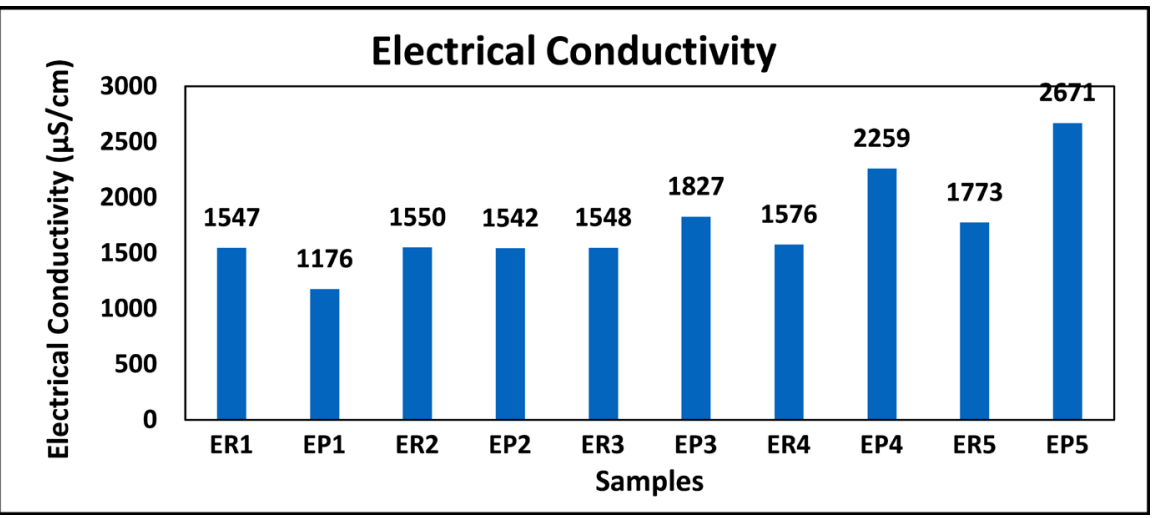

Figure 4. $\mathrm{pH}$ variations on drinking water of Hann Bel-Air Municipaly.

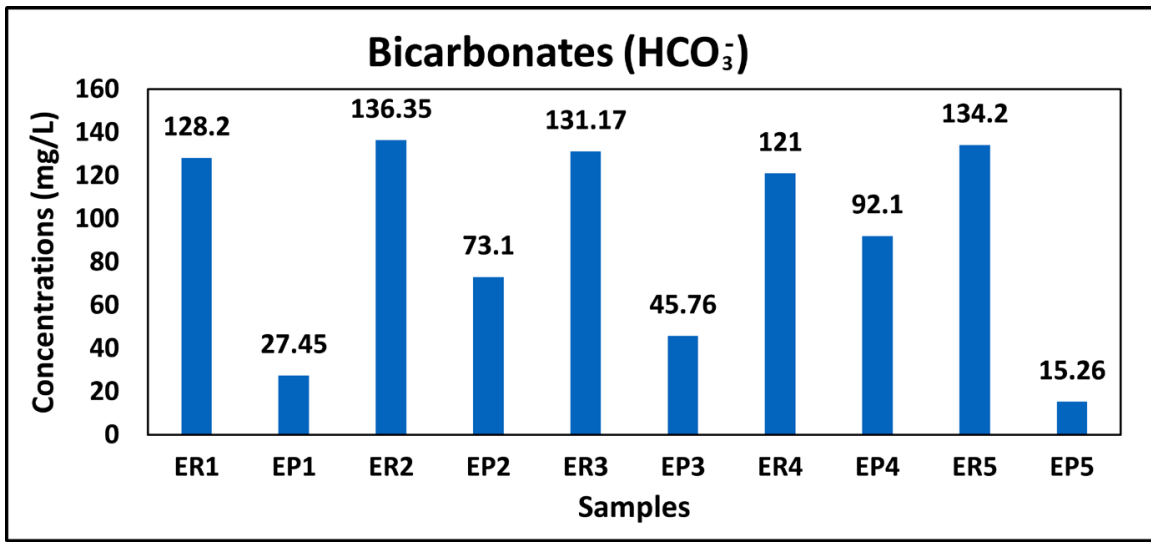

Figure 5. Bicarbonates $\left(\mathrm{HCO}_{3}^{-}\right)$variations on drinking water of Hann Bel-Air.

concentrations of tap water are higher than those of the ground water. However, both of them respect the $420 \mathrm{mg} / \mathrm{L}$ threshold set by the World Health Organization for which the most concentrated samples correspond to the basic samples.

The alkalinity of a water corresponds to the presence of hydrogenocarbonates or bicarbonates $\left(\mathrm{HCO}_{3}^{-}\right)$, carbonates $\left(\mathrm{CO}_{3}^{-}\right)$, hydroxide ions $\left(\mathrm{HO}^{-}\right)$and, to a lesser extent, silicate ions $\left(\mathrm{HSiO}_{3}^{-}\right)$, phosphates $\left(\mathrm{PO}_{3}^{-}\right)$or the molecular species of weak acids. Bicarbonate in water comes from the dissolution of $\mathrm{CO}_{2}$ gas in natural sources.

\subsection{Chlorides ( $\left.\mathrm{Cl}^{-}\right)$}

Chloride concentrations range from $271.13 \mathrm{mg} / \mathrm{L}$ to $464.02 \mathrm{mg} / \mathrm{L}$ (Figure 6), well above the threshold of $250 \mathrm{mg} / \mathrm{L}$ set by World Health Organization. The contents are higher in the water of the water table. This observation can be explained by the proximity of Hann Bel-Air is with the sea. This excess of chlorides causes an unpleasant taste especially when it comes to sodium chlorides $\mathrm{NaCl}$.

However, the presence of other ions in the water may affect the aroma in combination with the chlorides. They are also likely to cause corrosion in pipes and tanks, especially for stainless steel elements, where the risks increase from 50 $\mathrm{mg} / \mathrm{L}[13]$. 


\subsection{Nitrates $\left(\mathrm{NO}_{3}^{-}\right)$}

Nitrate concentrations range from $7.58 \mathrm{mg} / \mathrm{L}$ to $496.63 \mathrm{mg} / \mathrm{L}$ (Figure 7). For tap water, the levels obtained are below the World Health Organization threshold. For groundwater levels are above the threshold of $50 \mathrm{mg} / \mathrm{L}$ established by World Health Organization. These high levels can be explained by market gardening activities near our sampling areas.

Nitrates $\left(\mathrm{NO}_{3}^{-}\right)$have an indirect toxicity by the fact that they turn into nitrites.

\subsection{Sulfates $\left(\mathrm{SiO}_{4}^{2-}\right)$}

Sulphate concentrations range from $92.08 \mathrm{mg} / \mathrm{L}$ to $215.01 \mathrm{mg} / \mathrm{L}$ (Figure 8). Below the World Health Organization threshold of $250 \mathrm{mg} / \mathrm{L}$, the sulphate levels of tap water are lower than those of the water table. Very soluble in water, sulphates can be used as a source of oxygen. Converted into toxic sulphated hydrogen, sulphates make the taste unpleasant. This could be the cause of the unpleasant taste of the water from the tablecloth.

The presence of sulphates in the drinking water can give it a noticeable taste. At very high levels, sulphates can be laxative in non-habitual users [14]. The

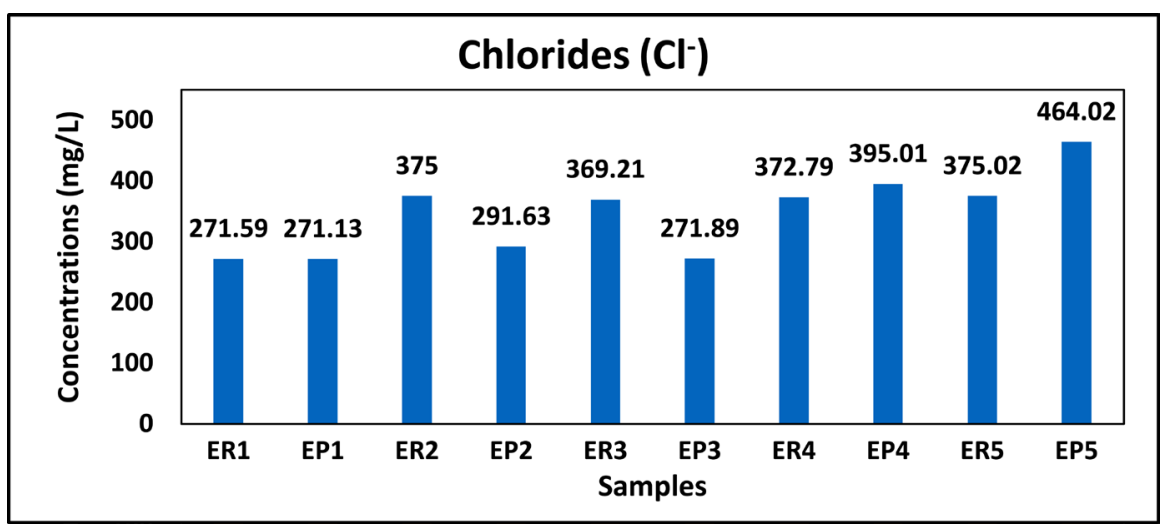

Figure 6. Chlorides $\left(\mathrm{Cl}^{-}\right)$variations on drinking water of Hann Bel-Air.

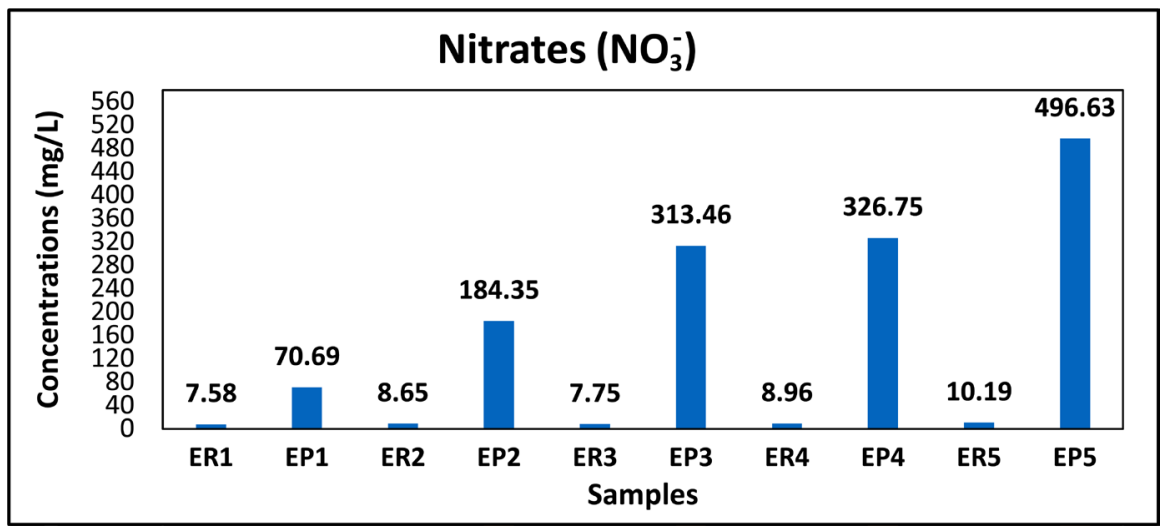

Figure 7. Nitrates $\left(\mathrm{NO}_{3}^{-}\right)$variations on drinking water of Hann Bel-Air. 


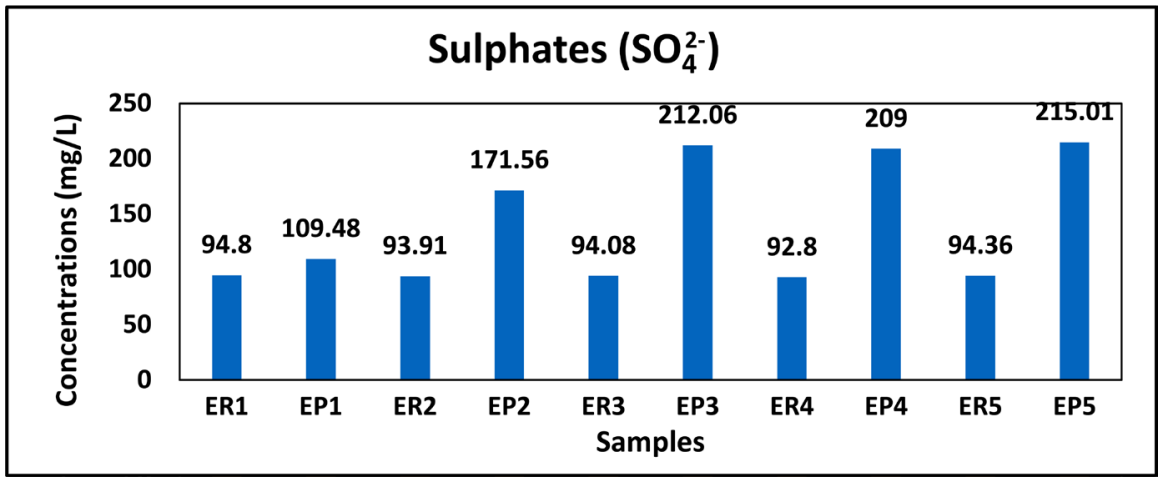

Figure 8. Sulfates $\left(\mathrm{SO}_{4}^{2-}\right)$ variations on drinking water of Hann Bel-Air.

alteration of taste varies with the nature of the associated cation. For water intended for human consumption, because of particular problems likely to introduce an inconvenience for the consumer (taste, corrosion), the World Health Organization recommend as limit value $250 \mathrm{mg} / \mathrm{L}$.

\subsection{Sodium $\left(\mathrm{Na}^{+}\right)$}

Concentrations of $\mathrm{Na}^{+}$vary from $174.98 \mathrm{mg} / \mathrm{L}$ to $331.27 \mathrm{mg} / \mathrm{L}$ (Figure 9). Sodium levels in tap water do not exceed the World Health Organization threshold of $200 \mathrm{mg} / \mathrm{L}$. Of the five (05) water samples from the water table, three samples EP3, EP4 and EP5 exceeded the drinking water threshold.

The proximity of the sea can explain the origin of these high $\mathrm{Na}$ content. Of all the salts, $\mathrm{Na}^{+}$is the best known of the populations. For reasons of consideration, World Health Organization recommend a limit value of $200 \mathrm{mg} / \mathrm{L}$. The threshold of sodium concentration in the water detectable by taste depends on the associated anion and the temperature of the solution. Sodium salts (eg sodium chloride) are all present in drinking water.

\subsection{Potassium $\left(\mathrm{K}^{+}\right)$}

We have levels that vary from the minimum value of $15.69 \mathrm{mg} / \mathrm{L}$ to the maximum value of $88.59 \mathrm{mg} / \mathrm{L}$ (Figure 10). The peak is recorded on EP3. Since there is no threshold value, there will be no thorough interpretation. Very soluble in water, potassium is a chemical element easily incorporated by aquatic organisms.

Given the low needs of human body ( 3 to $4 \mathrm{~g} / \mathrm{L}$ ), potassium is easily provided by food. According to the World Health Organization, no health-based recommendation has been made because of the low contribution of drinking water.

\subsection{Magnesium $\left(\mathrm{Mg}^{2+}\right)$}

The results of the samples show low values below $50 \mathrm{mg} / \mathrm{L}$ which is the guide value (Figure 11). Magnesium is a major element in the hardness of water. It is present in the form of carbonates or bicarbonates.

From a concentration of $100 \mathrm{mg} / \mathrm{L}$ and for sensitive subjects, magnesium gives 


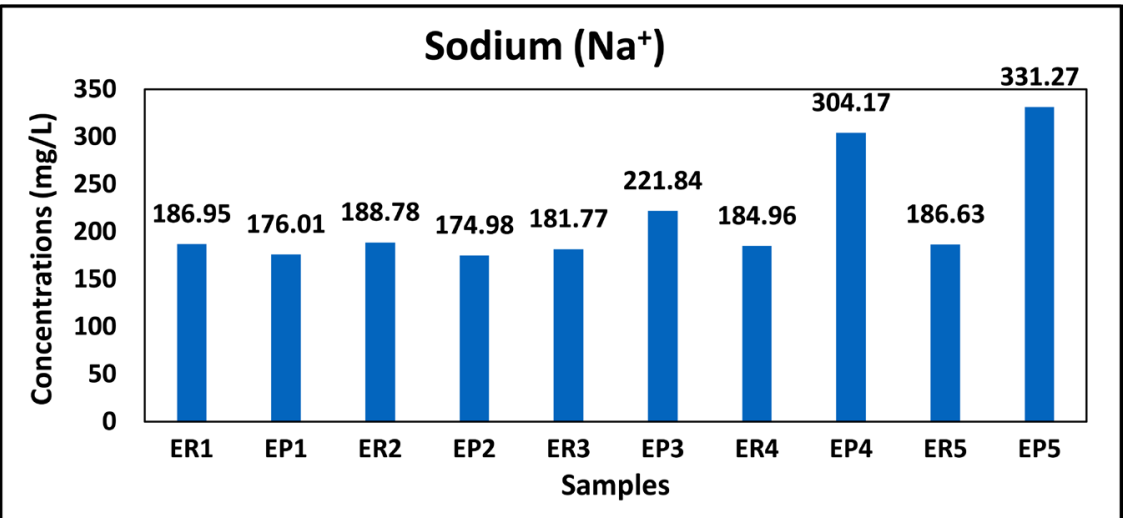

Figure 9. Sodium $\left(\mathrm{Na}^{+}\right)$variations on drinking water of Hann Bel-Air.

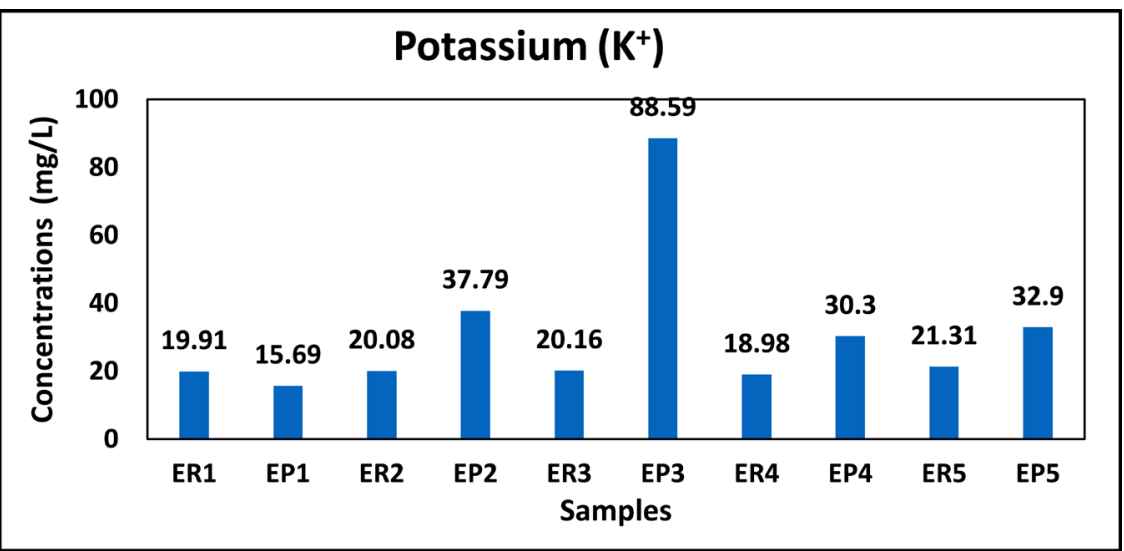

Figure 10. Potassium $\left(\mathrm{K}^{+}\right)$variations on drinking water of Hann Bel-Air.

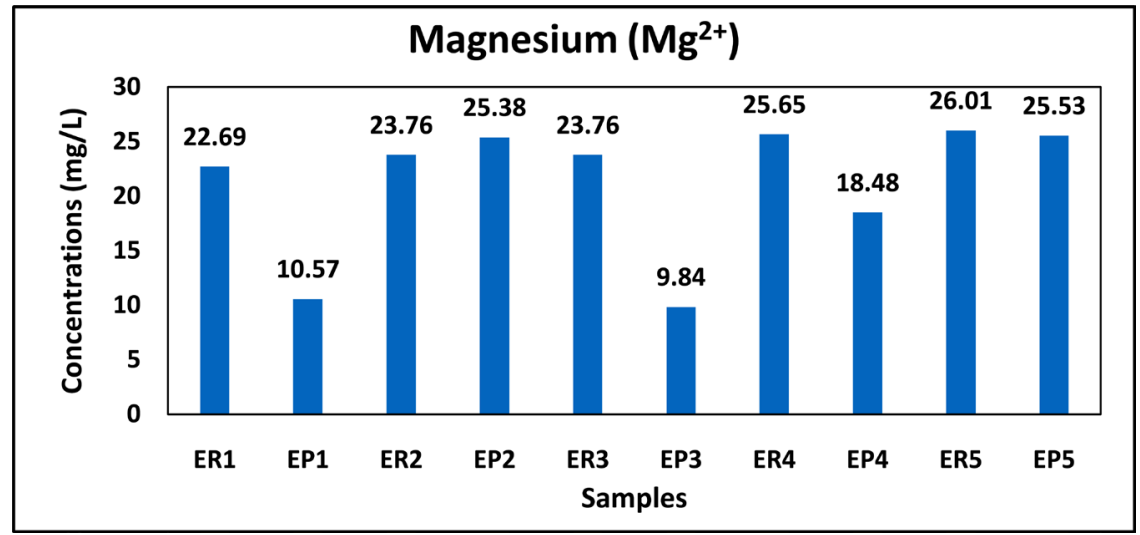

Figure 11. Magnesium $\left(\mathrm{Mg}^{2+}\right)$ variations on drinking water of Hann Bel-Air.

an unpleasant taste to water. If they do not cause toxic phenomena, magnesium salts and especially sulphates have a laxative effect from 400 to $500 \mathrm{mg} / \mathrm{L}$. This action decreases rapidly with the habit [14]. Officially, World Health Organization recommend not to exceed a value of $50 \mathrm{mg} / \mathrm{L}$ for magnesium.

\subsection{Calcium $\left(\mathrm{Ca}^{2+}\right)$}

The results show that calcium levels meet the threshold set by the World Health 
Organization (Figure 12). However, there is a big difference between the calcium levels recorded in samples EP1 and EP5 for aquifer waters. This difference in values shows the heterogeneity of aquifer waters. On the contrary, the tap water content is more or less homogeneous.

As a major component of water hardness, calcium is usually the dominant element of drinking water [12]. Its content is mainly related to the nature of the land. Water exceeding the threshold of $200 \mathrm{mg} / \mathrm{L}$ of calcium has serious disadvantages for domestic use.

\subsection{Iron $\left(\mathrm{Fe}^{2+}\right)$}

In tap water samples, iron levels range from $0.11 \mathrm{mg} / \mathrm{L}$ to $0.2 \mathrm{mg} / \mathrm{L}$ while the content in groundwater ranges from 0.19 and $0.25 \mathrm{mg} / \mathrm{L}$ (Figure 13).

Anaerobic groundwater may contain ferrous iron with concentrations up to several milligrams per liter without change in color or turbidity [15]. However, when exposed to air, ferrous iron oxidizes to ferric iron, giving the water an undesirable red color [15]. Iron stimulates the growth of iron bacteria by deriving its energy from the oxidation of ferrous iron and creates, during this process, a mucous layer on the piping [12].

At concentrations above $0.3 \mathrm{mg} / \mathrm{L}$ iron stains monitoring and piping. Iron

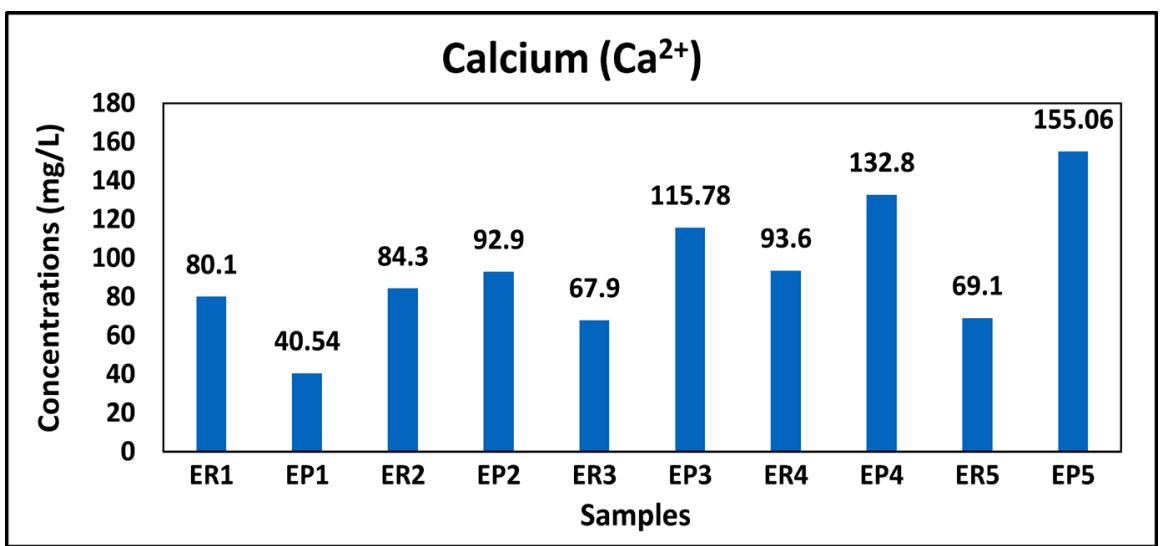

Figure 12. Calcium $\left(\mathrm{Ca}^{2+}\right)$ variations on drinking water of Hann Bel-Air.

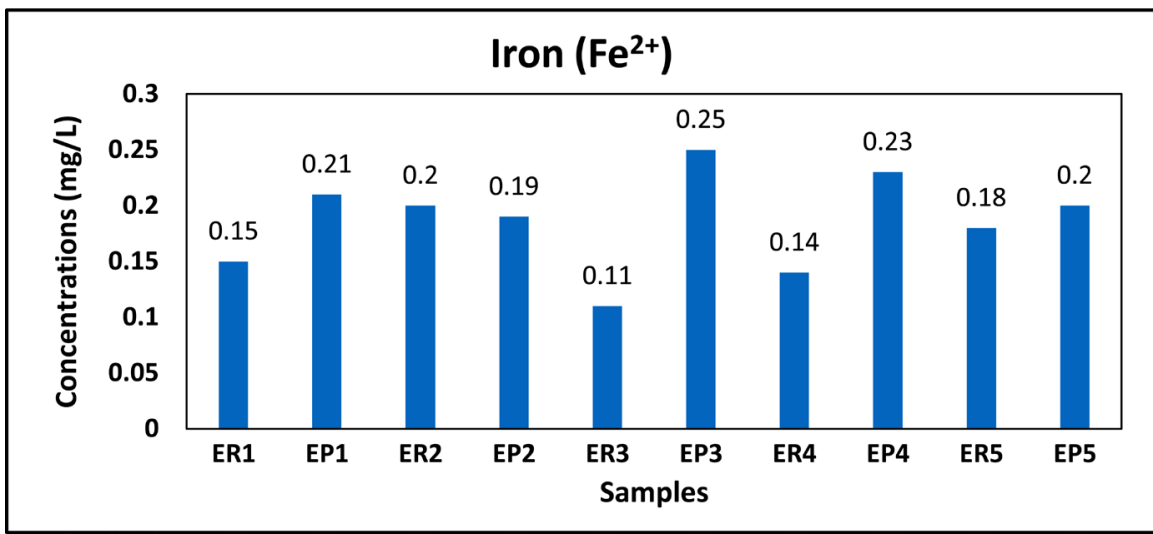

Figure 13. Iron $\left(\mathrm{Fe}^{2+}\right)$ variations on drinking water of Hann Bel-Air. 
concentration is generally not noticeable at concentrations below $0.3 \mathrm{mg} / \mathrm{L}$, which can be cloudy and cause color development [12]. No indicative value based on health arguments has been proposed for iron.

\section{Conclusions}

At the end of this study, it is noted that for both tap water and groundwater, the values of electrical conductivity are high compared to the threshold of 1000 $\mu \mathrm{S} / \mathrm{cm}$ set by the World Health Organization with a peak of $2671 \mu \mathrm{S} / \mathrm{cm}$. The $\mathrm{pH}$ of tap water is basic (varies from 7.03 to 7.09 ) so alkaline limit the effectiveness of disinfection with chlorine and that of water from the water table is acidic (varies from 6.4 to 6.9) therefore aggressive and may corrode the metal parts of Jambar pumps.

The physico-chemical results show that tap water and water table respect World Health Organization standards for bicarbonates and sulfates. Regarding nitrates, tap water complies with the World Health Organization threshold of 50 $\mathrm{mg} / \mathrm{L}$, unlike water from the water table, which is well above the threshold. With regard to chloride, the threshold $(250 \mathrm{mg} / \mathrm{L})$ is exceeded at all levels, but we can specify that the high concentrations of chloride are part of the derogations granted to the SDE. Tap water and water from the water table have concentrations of calcium, potassium, iron and magnesium irreproachable. With the exception of sodium which is high for three samples from the water up to a peak of $310.27 \mathrm{mg} / \mathrm{L}$.

In summary, tap water is more drinkable than groundwater, but its quality has to be improved and specially controlled for the well-being and sustainable health of consumers.

\section{Acknowledgements}

I sincerely thank the whole staff of the Laboratory of Hydrochemistry of the Department of Geology, Faculty of Sciences and Techniques, Cheikh Anta Diop University of Dakar (Senegal) for their precious collaboration.

\section{Conflicts of Interest}

The authors declare no conflicts of interest regarding the publication of this paper.

\section{References}

[1] Faye, C. (2017) Les défis de la pollution de l'eau, une menace pour la santé publique: Atouts et défauts des lois et politiques de l'eau au Sénégal. Larhyss Journal, 32, 107-126.

[2] Honegger, A. and Tabarly, S. (2011) La "gestion durable des ressources en eau" dans le bassin du Rhône, de la théorie à la pratique Université de Lyon, UMR/CNRS 5600 EVS) pour Géoconfluences. $12 \mathrm{p}$.

[3] Comite National Du Livre Bleu Senegal, Congad (2010) L'eau, la vie, le développement humain. Le secrétariat international de l'eau, 12 p. 
[4] Eric, B.B. (2004) The Implications of Formulating a Human Right to Water. Ecology Law Quarterly, 31, 957-959.

[5] World Health Organization (2008) Normes essentielles en matière de santé environnementale dans les structures de soins. Organisation mondiale de la Santé, Genève. http://whqlibdoc.who.int/publications/2010/9789242547238 fre.pdf?ua=1

[6] Black, R.E., Cousen, S., Johnson, H.L., Lawn, J.E., Rudan, I., Bassani, D.G., Jha, P., Campbell, H., Walker, C.F., Cibulskis, R., Eisele, T., Liu, L. and Mathers, C. (2010) Presentation for the Child Health Epidemiology Reference Group of World Health Organization and UNICEF. Global, Regional, and National Causes of Child Mortality in 2008: A Systematic Analysis. The Lancet, 375, 1969-1987. https://doi.org/10.1016/S0140-6736(10)60549-1

[7] Bâ, A. (2007) Les fonctions reconnues à l'agriculture intra et périurbaine (AIPU) dans le contexte dakarois; caractérisation, analyse et diagnostic de durabilité de cette agriculture et de son intégration dans le projet urbain de Dakar (Sénégal). Thèse de doctorat ès Sciences Agronomiques et de l'Environnement, AgroParisTech-UCAD, 356 p. et annexes.

[8] Cissé, I., Fall, A.S. and Fall, S.T. (2001) Caractéristiques de la zone des Niayes. In: Fall, et al., Cités horticoles en sursis? L'agriculture urbaine dans les Niayes au Sénégal, CRDI, Ottawa, 1-10.

[9] Baldé, Y. (2006) Contribution à l'étude de la qualité des eaux du réseau d'alimentation en eau potable de la ville de Dakar-Diagnostic et Propositions d'amélioration. Soutenu publiquement à l'Institut International d'Ingénierie de l'Eau et de l'Environnement, Ouagadougou, 76 p.

[10] Quensière, J. and Retière, A. (2013) Plan Climat Territorial Intégré de la Région de Dakar. Dakar Sénégal, 117 p.

[11] Diouf, B. (2011) Approvisionnement en eau potable et évacuation des eaux usées domestiques dans la ville de Thiès: Cas du quartier de DVF (Sénégal). 83 p.

[12] World Health Organization (2017) Les directives de qualité pour l'eau de boisson 4 ème édition. World Health Organization, pregny-chambésy (suisse), 564 p.

[13] Rodier, J. (1996) L'analyse de l'eau: Eaux naturelles-eaux usées. Troisième édition, DUNOD, Paris, 412 p.

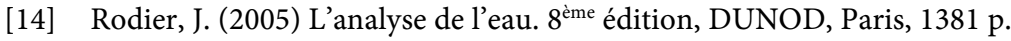

[15] Cheikh, F. (2007) Etude de la qualité de l'eau de robinet et celle de la nappe phréatique dans les différentes Communes d'Arrondissement du département de Guédiawaye. Mémoire soutenu publiquement à l'UCAD, $92 \mathrm{p}$. 